\title{
Relação entre o nevo melanocítico congênito pequeno e
} melanoma cutâneo*

\section{Small congenital melanocytic nevus and the risk of developing melanoma*}

\author{
Marcus Maia ${ }^{1}$ \\ Carla Russo ${ }^{2}$ \\ Manoel Carlos S. de A. Ribeiro ${ }^{4}$ \\ Helena Muller $^{5}$ \\ Nelson Ferrari² \\ Gabriela Di Giunta ${ }^{6}$ \\ Douglas Jorge $e^{3}$
}

Resumo: Fundamentos - 0 risco da ocorrência, de Melanoma Cutâneo (MC), no Nevo Melanocítico Congênito Pequeno (NMCP) ( $\leq$ $3 \mathrm{~cm}$ ), não tem sido motivo de estudos freqüentes ou mesmo recentes. A conduta a respeito de tais lesões ainda não apresenta nenhum consenso.

OBjetIvos - o propósito deste estudo foi avaliar a freqüência do melanoma cutâneo originado em Nevo Melanocítico Congênito Pequeno, e discutí-lo em relação a literatura, com propósitos de conduta prática.

CASUísticA E MÉtOdOS - de um total de 204 pacientes, com Melanoma Cutâneo, foram selecionados aqueles cuja doença foi originada de um Nevo Melanocítico Congênito Pequeno. 0 critério de inclusão foi clínico, baseado na informação do paciente.

RESULTADOS - Do total de 204 pacientes, 44(21,6\%) com Intervalo de Confiança (C) de 12,2 a 28,0\%, resultaram da transformação de um Nevo Congênito Melanocítico Pequeno. Nenhum caso ocorreu antes dos vinte anos e não houve uma faixa etária preferencial de transformação.

CONCLUSÕES - 0 Nevo Congênito Melanocítco Pequeno é precursor do Melanoma Cutâneo; a transformação, provavelmente, não ocorre antes da puberdade; o risco de transformação, após a puberdade, parece existir de forma homogênea por toda a vida. Sugestão: a excisão deve ser realizada no início da puberdade.

Palavras-chave: melanoma; nevo pigmentado.

Summary: BACKGROUND - There have been few studies, even recently, into the risk of occurrence of cutaneous melanoma in small congenital melanocytic nevi $\leq 3 \mathrm{~cm}$ ). There is no consensus regarding the management of these lesions.

OBJECTIVES - The purpose of the study was to evaluate the frequency with which small congenital melanocytic nevi transform into cutaneous melanoma and discuss this in relation to the literature, focussing on the practical management.

PATIENT AND METHODS - From a total of 204 patients with cutaneous melanoma, the authors selected those whose disease was derived from small congenital melanocytic nevi. The inclusion criterion was clinical, based on patient records.

RESULTS - Malignant transformation of small congenital melanocytic nevi was found in 44/204 patients (21.6\%) with con fidence interval $(\mathrm{Cl})$ of 12.2 to $28 \%$. . No cases occurred before 20 years of age and there was no preferential age range for the transformation.

CONCLUSION - Small congenital melanocytic nevi are a precursor lesion of cutaneous melanoma; the transformation most probably does not occur before puberty; while the risk of transformation after puberty seems to occur homogeneously throughout life. Suggestion: The excision should be performed at the onset of puberty.

Key-words: melanoma; nevus, pigmented.

\footnotetext{
Recebido em 06.09.2001. / Received in September, 06 ${ }^{\text {th }}$ of 2001.

Aprovado pelo Conselho Consultivo e aceito para publicação em 10.06.2002. / Approved by the Consultive Council and accepted for publication in June, $10^{\text {th }}$ of 2002.

* Trabalho realizado na Clínica de Dermatologia do Departamento de Medicina da Santa Casa de Misericórdia de São Paulo. / Work done at the Dermatology Clinic, Dept. of Medicine, "Santa Casa de Misericórdia de São Paulo"

Doutor, Chefe de Clínica Adjunto da Clínica de Dermatologia do Departamento de Medicina da Santa Casa de Misericórdia de São Paulo. / Ph.D., Adjunct Head of Dermatology Clinic, Dept. of Dermatology, "Santa Casa de Misericórdia de São Paulo"

Médico Dermatologista da Clínica de Dermatologia do Departamento de Medicina da Santa Casa de Misericórdia São Paulo. / M.D., Dermatologist, Dermatology Clinic, Dept. of Medicine, "Santa Casa de Misericórdia de São Paulo"

Professor Assistente do Departamento de Cirurgia Plástica da Santa Casa de Misericórdia de São Paulo. / Assistant Professor, Dept. of Plastic Surgery, "Santa Casa de Misericórdia de São Paulo"

${ }^{4}$ Professor Assistente do Departamento de Medicina Social da Faculdade de Ciências Médicas da Santa Casa de Misericórdia de São Paulo. $/$ Assistant Professor, Dept. of Social Medicine, School of Medical Sciences, "Santa Casa de Misericórdia de São Paulo"

Professor Adjunto do Departamento de Patologia da Santa Casa de Misericórdia de São Paulo. / Adjunct Professor, Dept. of Pathology, "Santa Casa de Misericórdia de São Paulo"

${ }^{6}$ Residente do Departamento de Patologia da Santa Casa de Misericórdia de São Paulo. / Resident, Dept. of Pathology, "Santa Casa de Misericórdia de São Paulo "
} 


\section{INTRODUÇÃO}

O reconhecimento das lesões precursoras do melanoma cutâneo é de suma importância para sua prevenção e condução. A transformação de um nevo melanocítico congênito gigante em melanoma cutâneo é bem conhecida e normalmente ocorre durante os primeiros 20 anos de vida, com risco de, pelo menos, 6,3\% ${ }^{1-7}$ Assim sendo, sua excisão preventiva precoce é recomendada, embora, na maioria das vezes, isso seja impossível, em função de seu tamanho e/ou localização.

Pouca atenção, entretanto, tem sido dada quando a origem da transformação é um nevo melanocítico congênito pequeno, havendo apenas escassos relatos na literatura.

Originalmente, a diferenciação entre o nevo melanocítico congênito pequeno e o grande foi feita exclusivamente por razões cirúrgicas, sendo depois classificado de acordo com seu tamanho. ${ }^{89}$ É importante saber se o tamanho é o único determinante de risco para o nevo melanocítico congênito, pois os pequenos são, pelo menos 10 vezes, mais comuns do que os gigantes..$^{10,11}$

O risco para melanoma cutâneo, no que se refere ao nevo melanocítico congênito pequeno e médio, ainda é matéria de controvérsia, ${ }^{12,13}$ embora as discussões sobre sua remoção preventiva sejam relativamente antigas. ${ }^{8,14,15,16}$ Kopf et al. ${ }^{8}$ consideraram rara a transformação de nevo congênito pequeno e recomendaram a observação contínua, como medida suficiente. Entretanto, Rhodes et al. ${ }^{17}$ avaliaram extensa casuística de melanoma cutâneo e demostraram que o nevo melanocítico congênito pequeno foi causa de transformação em $8,1 \%$ dos casos, com comprovação histológica, e em 14,9\% deles com história clínica. Esses dados permitiram aos autores estimar o risco cumulativo para melanoma entre $2,6 \%$ e $4,9 \%$ para pessoas com nevo melanocítico congênito pequeno que vivam até a idade de 60 anos. Como relatado acima, o fato de o nevo melanocítico congênito pequeno ser muito mais freqüente do que o gigante $(1 \% \text { vs. } 0,005 \%)^{17,18}$ e muitas vezes múltiplo permitiu aos autores concluir que seu potencial de malignidade deve ser de maior importância prática do que o do nevo gigante. Outra conclusão dos mesmos autores refere-se à transformação, que, em sua casuística, nunca ocorreu antes da puberdade, fato que os levou a sugerir que a excisão preventiva possa ser postergada até seu início.

Como a literatura referente ao potencial de transformação do nevo melanocítico congênito pequeno não está suficientemente discutida, os autores resolveram aqui rever seus registros, nos quais essa questão foi regularmente anotada. O resultado foi surpreendente e eles o discutem da forma mais ampla possível.

O objetivo deste estudo é de avaliar a frequiência do melanoma cutâneo originado em nevo melanocítico congênito pequeno, com base em material próprio, e discutir a questão em relação à literatura.

\section{CASUÍSTICA E MÉTODOS}

Entre maio de 1993 e maio de 2001, foram observa-

\section{INTRODUCTION}

The recognition of the precursory lesions of cutaneous melanoma is of great importance for its prevention and mana gement. The possibility of the transformation of a large conge nital melanocytic nevus into cutaneous melanoma is well known. This usually occurs during the first 20 years of life, with a risk rate of at least $6.3 \% .^{1.7}$ This being the case, its pre cocious preventive excision is recommended, although, most of the time this is impossible because of its size and/or location.

Little attention, however, has been given to cases in which the origin of the transformation is a small congenital melanocytic nevus and there are few reports of this in the literature.

Originally, the differentiation between small and large congenital melanocytic nevus was exclusively deter mined for surgical purposes, only later being classified according to their size. ${ }^{8,9}$ It is important to ascertain whe ther size is the only risk determinant for congenital mela nocytic nevus, since the small ones are at least ten times more common than the large ones. ${ }^{10,11}$

The level of risk for cutaneous melanoma in reference to small and medium congenital melanocytic nevus, is still a matter of controversy, ${ }^{12,13}$ although the discussions about its preventive removal are relatively old. ${ }^{8,1,1,15,16} \mathrm{Kopf}$ et al. ${ }^{8}$ consi dered the transformation of small congenital nevus to be rare. They recommended a continuing observation as a suffi cient measure. However, Rhodes et al. ${ }^{17}$ evaluated an extensi ve sample of patients with cutaneous melanoma and demons trated that the small congenital melanocytic nevus was the cause of the transformation in $8.1 \%$ of the cases using histo logical methods, and in 14.9\% of the cases using clinical his tory. These data allowed the authors to estimate the cumula tive risk for melanoma as being between $2.6 \%$ and $4.9 \%$ for people with small congenital melanocytic nevus that live to the age of 60. As mentioned above, the fact that the small congenital melanocytic nevus is much more frequent than the large $(1 \% \text { vs. } 0.005 \%)^{17,18}$ and often multiple enabled the authors to conclude that its malignant potential should in fact be considered of greater practical importance than that of the large nevus. Another conclusion of those same authors in reference to the transformation was that in their case studies, it never occurred before puberty, a fact that led them to sug gest that preventive excision can be postponed until its onset.

Since the literature does not sufficiently discuss the potential of transformation of the small congenital melanocy tic nevus, the authors resolved to review their records in which this aspect was regularly noted. The result was surprising and is discussed herein in the most ample manner possible.

Thus, the objective of this study was to evaluate the fre quency of cutaneous melanoma originating from small conge nital melanocytic nevus, based upon the authors' own material, and to discuss the subject in relation to the literature.

\section{PATIENTS AND METHODS}

Between May 1993 and May 2001, 204 patients with 
dos 204 pacientes com o diagnóstico de melanoma cutâneo na Unidade de Melanoma da Santa Casa de São Paulo (UMSC).

Todos os pacientes haviam sido inquiridos quanto ao fato de seu melanoma ter tido origem em uma "pinta" presente desde o nascimento. Só foram considerados como tal aqueles que o afirmaram categoricamente e cuja lesão media $3 \mathrm{~cm}$ ou menos.

Esse grupo foi considerado o de pacientes cujo melanoma cutâneo teve origem em um nevo melanocítico congênito pequeno, sendo então denominado nevo congênito (NC) e estudado quanto às variáveis sexo, cor, localização da lesão primária e idade na época do diagnóstico.

Em seguida esses dados foram comparados com a casuística correspondente aos pacientes cujo melanoma não teve origem em nevo melanocítico congênito pequeno, denominado nevo não congênito (NNC), para avaliar as possíveis diferenças estatísticas.

\section{RESULTADOS}

Do grupo total, de 204 pacientes com melanoma cutâneo, foram separados $44(21,6 \%)$, com intervalo de confiança de $95 \%$ de 12,2 a 28,0\%, cuja lesão primária resultou da transformação de um nevo congênito pequeno (grupo NC).

Quanto ao sexo, $18(40,9 \%)$ pertenciam ao masculino e $26(59,1 \%)$ ao feminino. Não houve diferenças estatísticas, quando estes resultados foram comparados ao grupo não melanoma (NNC), cuja lesão primária não derivou de um nevo congênito pequeno. Qui-quadrado de $0,17,1 \mathrm{gl}$, $\mathrm{p}=0,68$ (Tabela 1).

Quanto à cor, $41(93,2 \%)$ pacientes eram brancos e 3 $(7,8 \%)$ não brancos (pretos, pardos e amarelos). Da mesma forma, não existiu diferença estatística entre os dois grupos. Qui-quadrado de 1,57, $1 \mathrm{gl}, \mathrm{p}=021$ (Tabela 2).

Quanto à localização, 4 (9,1\%) estavam localizados na cabeça e pescoço; $10(22,7 \%)$ nos membros inferiores; 4 $(9,1 \%)$ nos membros superiores e $26(59,1 \%)$ no tronco. Quando esta distribuição, de localização, foi comparada com o outro grupo (NNC) ocorreram diferenças estatisticamente significantes (qui-quadrado de 21,36, 3gls, $\mathrm{p}<0,00001)$. Houve maior proporção de melanomas no tronco, no grupo de $\mathrm{NC}(59,1 \%$ contra $23,1 \%)$ (qui-quadra- a diagnosis of cutaneous melanoma were observed in the Melanoma Unit of Santa Casa, São Paulo (UMSC).

Each of the patients had been questioned about whe ther his or her melanoma originated from a "spot" present since birth. Only those cases were included in which the patient categorically affirmed this and when the lesion measured $3 \mathrm{~cm}$ or less.

This group was considered to be composed of patients whose cutaneous melanoma had origin in a small congenital melanocytic nevus, henceforth denominated con genital nevus $(C N)$. The group was studied relative to the fol lowing variables: gender, race, location of the primary lesion and age at the time of the diagnosis.

This data was then compared with the cases corres ponding to patients whose melanoma did not have a small congenital melanocytic nevus as its origin, this group was denominated non-congenital nevus (NCN). The possible sta tistical differences could then be evaluated.

\section{RESULTS}

From the total group of 204 patients with cutaneous melanoma, 44 (21.6\%), were selected with $95 \%$ confidence interval from 12.2 to $28.0 \%$, whose primary lesion resulted from the transformation of a small congenital nevus (Group CN).

As for gender, 18 (40.9\%) and $26(59.1 \%)$ were male and female, respectively. There was no statistically signifi cant difference when these results were compared to the non-melanoma group (NCN), whose primary lesion was not the result of a small congenital nevus. Chi-square $0.17,1 \mathrm{gl}$, $p=0.68$ (Table 1).

Regarding race, 41 (93.2\%) patients were white and $3(7.8 \%)$ non-white (black, mulatto or yellow). Likewise, there was no statistically significant difference between the two groups. Chi-square 1.57, $1 \mathrm{gl}, p=021$ (Table 2).

Relative to the location of the lesions, $4(9.1 \%)$ were in the head and neck; 10 (22.7\%) in the lower limbs; 4 (9.1\%) in the upper limbs and $26(59.1 \%)$ in the trunk. When the distri bution of location was compared with the other group (NNC) a statistically significant difference was revealed (Chi-square 21.36, $3 \mathrm{gls}, \mathrm{p}<0.00001)$. There was a larger proportion of melanomas in the trunk among the CN group (59.1\% against $23.1 \%$ ) (Chi-square 20.9, $1 \mathrm{gl}, \mathrm{p}<0.00001$ ) and a greater

Tabela 1: Distribuição quanto ao sexo, dos casos de melanoma cutâneo derivados de nevo congênito pequeno (NC) e do não nevo congênito (NNC), na Unidade de Melanoma da Santa Casa de Misericórdia de São Paulo, entre maio de 1993 e maio de 2001. / Table 1: Distribution according to sex, of the cases of cutaneous melanoma derived from small congenital nevi (CN) and non congenital nevi (NCN), at the Melanoma Unit of the Santa Casa de Misericórdia de São Paulo Hospital between May 1993 and May 2001

\begin{tabular}{|c|c|c|c|c|c|c|}
\hline \multirow[b]{2}{*}{ Sexo / Sex } & \multicolumn{2}{|c|}{$\mathrm{NC} / \mathrm{CN}$} & \multicolumn{2}{|c|}{$\mathrm{NNC} / N C N$} & \multicolumn{2}{|c|}{ Total } \\
\hline & Freq. & $\%$ & Freq. & $\%$ & Freq. & $\%$ \\
\hline Masculino / Male & 18 & 40.9 & 60 & 37.5 & 78 & 38.2 \\
\hline Feminino / Female & 26 & 59.1 & 100 & 62.5 & 126 & 61.8 \\
\hline Total & 44 & 100.0 & 160 & 100.0 & 204 & 100.0 \\
\hline
\end{tabular}


Tabela 2: Distribuição quanto a cor, dos casos de melanoma cutâneo derivados de nevo congênito pequeno (NC) e do não nevo congênito (NNC), na Unidade de Melanoma da Santa Casa de Misericórdia de São Paulo, entre maio de 1993 e maio de 2001. / Table 2: Distribution according to skin color of the cases of cutaneous melanoma derived from small congenital nevi (CN) and non congenital nevi (NCN), at the Melanoma Unit of the Santa Casa de Misericórdia de São Paulo Hospital between May 1993 and May 2001.

\begin{tabular}{|c|c|c|c|c|c|c|}
\hline \multirow[b]{2}{*}{ Cor / Color } & \multicolumn{2}{|c|}{$\mathrm{CN} / \mathrm{CN}$} & \multicolumn{2}{|c|}{$\mathrm{NNC} / \mathrm{NCN}$} & \multicolumn{2}{|c|}{ Total } \\
\hline & Freq. & $\%$ & Freq. & $\%$ & Freq. & $\%$ \\
\hline Branco / White & 41 & 93.2 & 137 & 85.6 & 178 & 87.3 \\
\hline Preto / Black & 1 & 2.3 & 8 & 5 & 9 & 4.4 \\
\hline Pardo / Mixed & 2 & 4.5 & 14 & 8.8 & 16 & 7.8 \\
\hline Amarelo / Yellow & 0 & 0.0 & 1 & 0.6 & 1 & 0.5 \\
\hline Total & 44 & 100.0 & 160 & 100.0 & 204 & 100.0 \\
\hline
\end{tabular}

do 20,9, $1 \mathrm{gl}, \mathrm{p}<0,00001)$ e maior proporção nos membros inferiores, no grupo NNC $(41,3 \%$ contra $22,7 \%)$, com quiquadrado 5,07, $1 \mathrm{gl} \mathrm{e} \mathrm{p=0,02} \mathrm{(Tabela} 3$ ).

Quanto à idade, a média foi 49,1 anos para o grupo NC, com desvio padrão de 20,5 e no grupo NNC foi de 60,8 anos com desvio padrão de 16,94 , sendo estatisticamente diferente com $\mathrm{t}=4,17,203 \mathrm{gl}$ e $\mathrm{p}<0,0001$.

A distribuição por faixa etária (intervalo de 20 anos), mostrou no grupo NC, nenhum caso abaixo dos 20 anos; 13 $(29,5 \%)$ de 20 a 39 anos; $17(38,6 \%)$ de 40 a 59 anos; 13 $(29,5 \%)$ de 60 a 79 anos e 1 caso $(2,3 \%)$ de 80 a 99 anos. No outro grupo, 1 caso $(0,6 \%)$ abaixo dos vinte anos; 18 $(11,3 \%)$ de 20 a 39 anos; $48(30 \%)$ de 40 a 59 anos; 78 $(48,8 \%)$ de 60 a 79 anos e $15(9,4 \%)$ de 80 a 99 (Tabela 4 e Gráfico 1).

\section{DISCUSSÃO}

Tem-se como norma, na Unidade de Melanoma da Santa Casa de São Paulo, o preenchimento de um protocolo, do qual uma das questões se refere à possível origem do melanoma cutâneo a partir de lesões precursoras, como nevo melanocítico congênito gigante, nevo melanocítico proportion in the lower limbs, in the NCN group $(41.3 \%$ against 22.7\%), Chi-square 5.07, $1 \mathrm{gl}$ and $p=0.02$ (Table 3).

In terms of age, the mean was 49.1 years in the $C N$ group, with a standard deviation of 20.5 and in the NCN group it was 60.8 years with standard deviation of 16.94, representing a statistically significant difference, $t=4.17$, $203 \mathrm{gl}$ and $p<0.0001$.

The distribution according to age group (20-year inter vals), showed that in the CN group, there was no case below 20 years of age; 13 (29.5\%) from 20 to 39 years; 17 (38.6\%) from 40 to 59 years; 13 (29.5\%) from 60 to 79 years; and one case (2.3\%) from 80 to 99 years. In the NCN group there was: one case $(0.6 \%)$ below twenty years; $18(11.3 \%)$ from 20 to 39 years; $48(30 \%)$ from 40 to 59 years; 78 (48.8\%) from 60 to 79 years and 15 (9.4\%) from 80 to 99 (Table 4 and Graph 1).

\section{DISCUSSION}

It is routine, in the Melanoma Unit of Santa Casa of São Paulo, to fill out a questionnaire on the patient in which one of the questions refers to the possible origin of the cuta neous melanoma as having started from precursory lesions, such as large congenital melanocytic nevus, acquired mela -

Tabela 3: Distribuição quanto a localização das lesões primárias, dos casos de melanoma cutâneo derivados de nevo congênito pequeno (NC) e do não nevo congênito (NNC), na Unidade de Melanoma da Santa Casa de Misericórdia de São Paulo, entre maio de 1993 e maio de 2001./ Table 3: Distribution according to location of the primary lesions of the cases of cutaneous melanoma derived from small congenital nevi (CN) and non congenital nevi (NCN), at the Melanoma Unit of the Santa Casa de Misericórdia de São Paulo Hospital between May 1993 and May 2001.

\begin{tabular}{|c|c|c|c|c|c|c|}
\hline \multirow[b]{2}{*}{ Local / Site } & \multicolumn{2}{|c|}{$\mathrm{NC} / \mathrm{CN}$} & \multicolumn{2}{|c|}{$\mathrm{NNC} / N C N$} & \multicolumn{2}{|c|}{ Total } \\
\hline & Freq. & $\%$ & Freq. & $\%$ & Freq. & $\%$ \\
\hline Cabeça / Head & 4 & 9.1 & 37 & 23.1 & 41 & 20.1 \\
\hline MMII / $L L \dagger$ & 10 & 22.7 & 66 & 41.3 & 76 & 37.2 \\
\hline MMSS / UL $\ddagger$ & 4 & 9.1 & 20 & 12.5 & 24 & 11.8 \\
\hline Tronco / Trunk & 26 & 59.1 & 37 & 23.1 & 63 & 30.9 \\
\hline Total & 44 & 100.0 & 160 & 100.0 & 204 & 100.0 \\
\hline
\end{tabular}

† Lower Limbs

$\ddagger$ Upper Limbs 
Tabela 4: Distribuição quanto a idade na época do diagnóstico, dos casos de melanoma cutâneo derivados de nevo congênito pequeno ( NC) e do não nevo congênito (NNC), na Unidade de Melanoma da Santa Casa de Misericórdia de São Paulo, entre maio de 1993 e maio de 2001

Table 4: Distribution according to age at diagnosis of the cases of cutaneous melanoma derived from small congenital nevi (CN) and non congenital nevi (NCN), at the Melanoma Unit of the Santa Casa de Misericórdia de São Paulo Hospital between May 1993 and May 2001.

\begin{tabular}{|c|c|c|c|c|c|c|}
\hline \multirow[b]{2}{*}{ Idade / Age (Yrs) } & \multicolumn{2}{|c|}{$\mathrm{NC} / \mathrm{CN}$} & \multicolumn{2}{|c|}{$\mathrm{NNC} / \mathrm{NCN}$} & \multicolumn{2}{|c|}{ Total } \\
\hline & Freq. & $\%$ & Freq. & $\%$ & Freq. & $\%$ \\
\hline 0 a 19 & 0 & 0.0 & 1 & 0.6 & 1 & 0.5 \\
\hline 20 a 39 & 13 & 29.5 & 18 & 11.2 & 31 & 15.2 \\
\hline 40 a 59 & 17 & 38.7 & 48 & 30.0 & 65 & 31.9 \\
\hline 60 a 79 & 13 & 29.5 & 78 & 48.8 & 91 & 44.6 \\
\hline 80 a 99 & 1 & 2.3 & 15 & 9.4 & 16 & 7.8 \\
\hline Total & 44 & 100.0 & 160 & 100.0 & 204 & 100.0 \\
\hline
\end{tabular}

adquirido, nevo atípico, lentigo maligno, nevo azul e também nevo congênito pequeno.

Sempre chamou atenção da equipe a referência dos pacientes quanto à origem de seu melanoma a partir de um nevo melanocítico congênito pequeno. Entretanto, a casuística pequena e a pouca referência na literatura quanto a esse fato retardaram as observações. Contudo, assim que foi alcançado determinado número de casos avaliáveis sob o ponto de vista estatístico sentiu-se necessidade de estudá-los, pois a associação entre nevo melanocítico congênito pequeno e melanoma aparecia de forma relevante na casuística.

A primeira questão refere-se ao depoimento inicial do paciente, considerando que seu melanoma teve origem em uma "pinta," presente desde o nascimento, portanto, num nevo melanocítico congênito pequeno. Trata-se de referência na qual poder-se-ia não ter confiança, como acreditam alguns autores, ${ }^{20}$ seja pela pouca importância que os pacientes poderiam dar a uma mancha pequena (até $3 \mathrm{~cm}$ ) presente desde o nascimento, seja por se tratar de paciente idoso, cujo depoimento materno não poderia ser confirmado. Entretanto, pelo fato de sempre ter estado preocupados com o assunto, o inquérito foi realizado de forma rigorosa $\mathrm{e}$ somente foram relacionados para este grupo (NC) aqueles pacientes que convictamente conheciam a origem congênita do seu nevo (morbidade referida). Portanto, é natural supor que a casuística pudesse até ser maior.

Pretende-se realizar em trabalho futuro uma avaliação histopatológica desses casos, com o objetivo de procurar resíduos de nevo congênito junto às células do melanoma. Supõem, entretanto, que justamente esse tipo de avaliação determinou a pouca importância para o potencial de transformação do nevo melanocítico congênito pequeno, com base sobretudo na possibilidade da total ocupação lesional pelas células neoplásicas, discussão, porém, que deve ser mais bem substanciada.

Considerando válida a metodologia aplicada, foram selecionados, de 204 pacientes, 44 cujo melanoma cutâneo, provavelmente, originou-se de um nevo melanocítico con- nocytic nevus, atypical nevus, lentigo maligna, blue nevus and also small congenital nevus.

Any reference by the patient to the origin of his/her melanoma having been a small congenital melanocytic nevus was also noted by the team. However, the small number of cases and the few references in the literature hampered the observations. Nevertheless, as soon as a sufficient number of cases had been evaluated for the purposes of statistical analysis, it was decided to undertake an investigation since there appeared to be a relevant association between congen ital melanocytic nevus and melanoma among these patients.

The first question arises in reference to the patient's initial statement that his/her melanoma had origin in a "spot" existing since birth, or that is, a small congenital melanocytic nevus. This makes use of reference material that some authors believe may be unreliable. The unreliability stems from the unimportance that patients might impute to a small stain (up to $3 \mathrm{~cm}$ ) present from birth or in dealing with an elderly patient, for whom maternal confirmation would not be available. However, due to the constant interest in the subject, the research was carried out in a rigorous manner and only those patients that confirmed with certainty that their nevus had a congenital origin (referred morbidity) were included in this group (CN). Therefore, it is natural to suppose that this group could be even larger.

The authors intend to carry out a future study involving a histopathological evaluation of these cases, with the objec tive of detecting residues of congenital nevus together with the melanoma cells. They suspect, however, that it was precisely this kind of evaluation that led to the view that the potential for transformation of small congenital melanocytic nevus was of little importance, and that this was based above all on the pos sibility of total lesional occupation of the neoplastic cells. This argument, however, should be better substantiated.

Considering valid the methodology to be applied, from a total of 204 patients, 44 patients were selected whose cutaneous melanomas probably arose from small congenital melanocytic nevus. That proportion was surprisingly high 
gênito pequeno. Essa proporção foi surpreendentemente elevada $(21,6 \%$ com intervalo de confiança de $95 \%$ de 12,2 a $28 \%$ ) e comparável aos relatos da literatura: Rhodes $^{17}$ refere $14,9 \%$ de 234 pacientes. Neste estudo, essa freqüência pôde ser determinada em um grupo pequeno de pacientes, mas consecutivo e homogêneo. Acredita-se que essa amostra seja representativa e também que esse índice, provavelmente, represente uma frequiência mínima. Considerando a freqüência como surgiu no material e a concordância com os poucos trabalhos da literatura, o nevo melanocítico congênito pequeno pode ser considerado precursor do melanoma cutâneo.

A avaliação quanto a sexo e cor dos pacientes não demonstrou diferenças estatísticas entre os dois grupos, nevo congênito (NC) e nevo não congênito (NNC), não merecendo, portanto, qualquer comentário relevante. $\mathrm{Na}$ literatura, nos poucos trabalhos referentes ao assunto, não foi encontrada qualquer nota a respeito.

Quanto à localização da lesão primária, o estudo dos dois grupos mostrou diferença estatisticamente significante para maior proporção de melanoma no tronco, no grupo NC. Isso se deve, provavelmente, ao fato de que o nevo melanocítico congênito pequeno é, em geral, mais freqüente nessa localização. ${ }^{19}$

Ainda em relação à localização, outra diferença estatisticamente significante foi a maior proporção de melanomas nos membros inferiores no grupo NNC, que poderia ser explicada pela elevada freqüência de melanoma acrolentiginoso nesse grupo $(24,3 \%$ contra $11,4 \%)$ (Qui-quadrado 5,89, $1 \mathrm{gl}, \mathrm{p}=0,02)$, cuja localização preferencial é exatamente essa.

Avaliando a distribuição por idade, verificou-se que o melanoma ocorreu em média de idade inferior no grupo NC (49,1 anos) em comparação à do grupo NNC $(60,8$ anos). Aqui, da mesma forma, o grupo NNC apresenta elevada freqüência de melanoma acrolentiginoso $(29,4 \%)$, que, como se sabe, ocorre em fase tardia da vida.

Quanto à distribuição por faixa etária (Gráfico 1), obteve-se curva mais achatada para ocorrência de melanoma no grupo NC, enquanto o grupo NNC revelou um pico na faixa de 60 a 79 anos. Esse gráfico demonstra, de forma relevante, que o risco de transformação do nevo melanocítico congênito pequeno é semelhante em qualquer época da vida, após a puberdade. Nos dois grupos verifica-se que o melanoma praticamente não ocorre antes da puberdade, o que, como se sabe, tem sua exceção no nevo congênito gigante. Essa observação coloca o nevo melanocítico congênito pequeno como fator de risco após a puberdade, porém diferindo do grupo NNC, já que a possibilidade de transformação é homogênea por toda vida.

\section{CONCLUSÃO}

Os resultados levam às seguintes conclusões práticas: - o nevo melanocítico congênito pequeno é precursor do melanoma cutâneo;

- a transformação, provavelmente, não ocorre antes da puberdade;

- o risco de transformação após a puberdade parece existir
(21.6\% 95\% confidence interval from 12.2 to $28 \%$ ) and com parable to reports in the literature: Rhodes ${ }^{17}$ refers to $14.9 \%$ from a sample of 234 patients. In this study, that frequency could be determined in a small but consecutive and homoge neous group of patients. It was considered that this sample was representative and also that this ratio probably represents a minimum frequency. Considering the frequency as it appeared in the research material and its agreement with the few works of the literature, small congenital melanocytic nevus can indeed be considered a precursor of cutaneous melanoma.

The evaluation by gender and patients' race did not demonstrate statistical differences between the two groups, congenital nevus (CN) or non-congenital nevus (NCN); hence no further comment is necessary relevant to this. Furthermore, no findings in this regard were described in the few works in relation to the subject in the literature.

As for the location of the primary lesion, analysis of the two groups showed a statistically significant difference for a higher proportion of melanoma in the trunk among group NC. This is probably due to the fact that small congenital melanocytic nevus is generally more frequently found in that location. ${ }^{19}$

Additionally, regarding the location, another statistically significant difference was in the greater proportion of melano mas in the inferior members in group NNC. This could be explai ned by the high frequency of acral lentiginous melanoma in that group (24.3\% against $11.4 \%$ ) (Chi-square 5.89, 1 gl, $p=0.02$ ), which is exactly the preferential location of that melanoma.

When evaluating the distribution according to age group, it was noted that melanoma occurred on average at a younger age in group CN (49.1 years) in comparison with group NCN (60.8 years). Here again, group NCN presents a high frequency of acral lentiginous melanoma (29.4\%), which, as it has been demonstrated, occurs in a later phase of life.

As for distribution by age group (Graph 1), flatter curves were obtained for melanoma occurrence in group $C N$, while group NCN revealed a peak in the period from 60 to 79 years. This graph demonstrates, in a relevant manner, that the risk of transformation of the small conge nital melanocytic nevus is much the same in any period of life after puberty. In both groups it was shown that mela noma practically never occurs before puberty, except in the case of large congenital nevus. This observation indi cates small congenital melanocytic nevus as a risk factor after puberty, although differing from the NCN group, since the possibility of transformation is homogeneous throughout the entire lifetime.

\section{CONCLUSION}

The results lead to the following practical conclusions: - small congenital melanocytic nevus is a precursor of cuta neous melanoma;

- transformation will probably not occur before puberty;

- transformation risk after puberty seems to exist in a homo geneous way throughout life; 


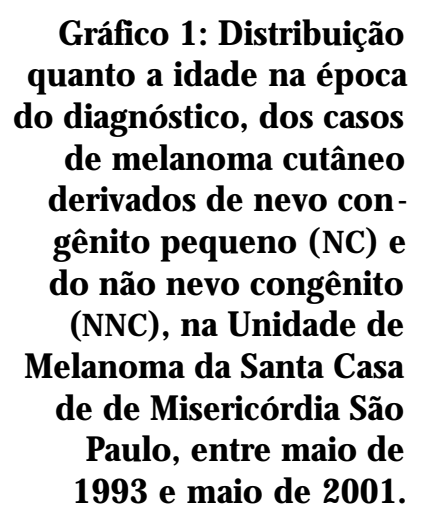

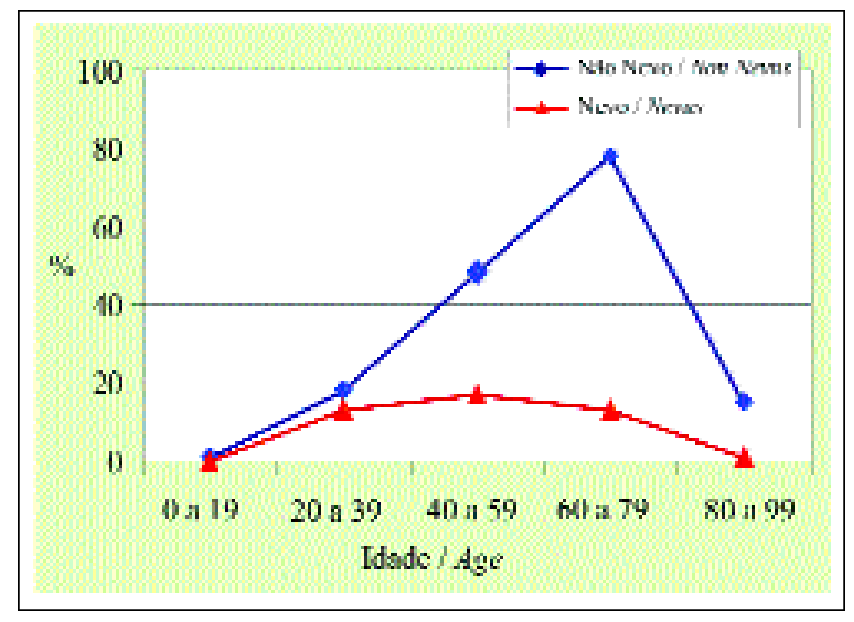

Graph 1 - Distribution according to age at diag nosis of the cases of cuta neous melanoma derived from small congenital nevi (CN) and non congenital nevi (NCN), at the Melanoma Unit of the Santa Casa de Misericórdia de São Paulo Hospital between May 1993 and May 2001. de forma homogênea por toda vida;

- a localização anatômica do nevo melanocítico congênito pequeno não altera o risco de transformação.

Essas conclusões, em conjunto com as de outros autores, ${ }^{17,20}$ permitem a seguinte sugestão: de acordo com o estudo como um todo, pode-se sugerir, do ponto de vista prático, que a excisão deve ser o método profilático de escolha para nevo melanocítico congênito pequeno e deve ser realizada no início da puberdade. Além do mais, este estudo é um convite aos autores para que as observações a respeito do nevo melanocítico congênito pequeno sejam ampliadas.

\section{REFERÊNCIAS / REFERENCES}

1. Rhodes A R, Wood W C, Sober A J, Mihm M C: Non-epidermal origin of malignant melanoma associated with a giant congenital nevocellular nevus. Plast Reconstr Surg 1981; 67:782-790.

2. Reed W B, Becker S W Jr, Nickel W R: Giant pigmented nevi, Melanoma and leptomeningeal melanocytosis: A clinical and histopathological study. Arch Dermatol 1965; 91:100-119.

3. Skov-Jensen T, Hastrup J, Lambrethsen E: Malignant melanoma in children. Cancer 1966; 19:620-626.

4. Fish J, Smith F B, Canby A J: Malignant melanoma in childhood. Surgery 1966; 59:309-315.

5. Kaplan E N: The risk of malignancy in large congenital nevi. Plast Reconstr Surg 1974; 53:421-428.

6. Lanier V C, Pickrell R L, Georgiade N G: Congenital giant nevi: Clinical and pathological considerations. Plast Reconstr Surg 1976; 58:48-54.

7. Hendrickson M R, Ross J C: Neoplasms arising in congenital giant nevi: Morphological study of seven casis and a review of literature. Am J Surg Pathol 1981; 5:109-135.

8. Kopf AW, Bart RS, Hennessey P: Congenital nevocytic nevi and malignant melanomas. J Am Acad Dermatol 1979;1:123-130.

9. Mark GJ, Mihm MC, Liteplo MG, et al: Congenital melanocytic nevi ofthe small and garment type: Clinical, histhologic and ultrastructural studies. Hum Pathol 1973;4:395-418.

10. Alper J, Holmes LB, Mihm MC: Birthmarks with serious medical significance: Nevocellular nevi, sebaceous nevi, and multiple café-au-lait spots. J Pediatr 1979;95;696-700.

11. Castilla EE, Da Graca Dutra M, Orioli-Parreiras IM: Epidemiology of congenital pigment nevi; incidence rates and relative frequencies. Br J Dermatol 1981;104:307-315.

12. Precursors to malignant melanoma (special report). National
- the anatomical location of a small congenital melanocytic nevus does not alter the transformation risk.

These conclusions, together with those of other authors, ${ }^{17,20}$ enable the following suggestion: in accordance with the study as a whole, it can be concluded, from the prac tical point of view, that excision should be the prophylactic method of choice for small congenital melanocytic nevus. This should be performed at the beginning of puberty. Finally, this study serves as an invitation to other authors interested in small congenital melanocytic nevus to enlarge upon these observations.

Institutes of Health, Consensus Development Conference Statment, Oct 1983. J Am Acad Dermatol 1984;10:683-688.

13. Arons MS, Hurwitiz S. Congenital nevocellular nevus: a review of the treatment controversy and a report of 46 cases. Plast Reconstr Surg 1983;72:355-365.

14. From L. Removal of congenital nevi-cons. Adv Dermatol 1987; 2:97-106.

15. From L. Congenital nevi: let's be practical. Pediatr Dermatol 1992;9:345-346.

16. Clemmense O, Ackerman AB. All small congenital nevi need not be removed (perspectives in dermopathology). Am J Dermopathol 1984;6:189-194.

17. Rhodes AR The Malignant potencial of small congenital nevocellular nevi: An estimate of association based on a histhologic study of 234 primary cutaneous melanoma. J Am Acad Dermatol 1982;6:230-241.

18. Rhodes AR, Melski JW: Small congenital nevocellular nevi and the risk of cutaneous melanoma. J Pediatr 1982;100:219-224. 19. Sahin S, Levin L, Kopf AW, et al: Risk of melanoma in medium-sized congenital melanocytic: A follow-up study. J Am Acad Dermatol 1998; 39:428-433.

20. Illig L, Weidner F, Hundeiker M, et al: Congenital nevi $£ 10 \mathrm{~cm}$ as precursors to Melanoma. Arch Dermatol 1985;121:1274-1281.

ENDEREÇO PARA CORRESPONDÊNCIA: / MAILING ADDRESS:
Marcus Maia
Rua Turiaçu, 143 conj.123
São Paulo SP 05005- 001
Tel/Fax: (11) 36675002
E-mail: marcusmaiasp@uol.com.br

